\title{
GOD WHEN SMILING CREATED HIM (KASEPUHAN SINAR RESMI OF SUKABUMI REGENCY WEST JAVA INDONESIA)
}

\author{
By : \\ ENDANG NARYONO \\ STIE PASIM SUKABUMI Lecturer \\ rtumarima@gmail.com
}

\begin{abstract}
ION
An increasingly advanced world with the development of science that is increasingly fast has a huge impact on this modern human civilization, eroding the pattern of human behavior from traditional to modern. One of the massive changes at this time is very high industrialization as a form of government programs in equitable development and the realization of the nation's great ideals of social justice for all Indonesian people. Agricultural land into factories and housing makes agricultural land shrinking, livelihoods from agriculture become factory workers due to the modernization of industry so far. One of the behaviors that are no less shifting is creativity, human initiative that reflects the personality as a nation begins to fade, such as hospitality, courtesy, religion and mutual cooperation which are the identity of the Indonesian nation which has the philosophy of Pancasila as the basis of the state. Now it has begun to shift, tending to imitate western, Japanese and European civilizations, they seem to enjoy and be proud of everything from language, food, association to foreign-made products. But not everything has changed, namely in the traditional village of Sinar Resmi, Sukabumi Regency, a village that holds fast to tradition even though times have changed, a simple life, mutual cooperation and the same fate. The vast expanse of agricultural land with suitable gardens without a touch of modernization, ways of socializing with mutual cooperation and hospitality and courtesy towards parents, leaders, fellow students and guests are still upheld. The extraordinary natural beauty that is very beautiful makes you feel at home and comfortable like heaven on earth, it's only natural that someone says that God is smiling when he creates it.
\end{abstract}

Key Word : Kasepuhan sinar resmi

\section{KASEPUHAN SINAR RESMI}

Kesepuhan Sinar Resmi is located in Sirna Resmi Village, Cisolok District, Sukabumi Regency, which is located between the border of West Java and Banten Provinces. Thus, it is included in the category of Indigenous area known as the "Banten Kidul Kasepuhan Sinar Resmi Traditional Unit". 


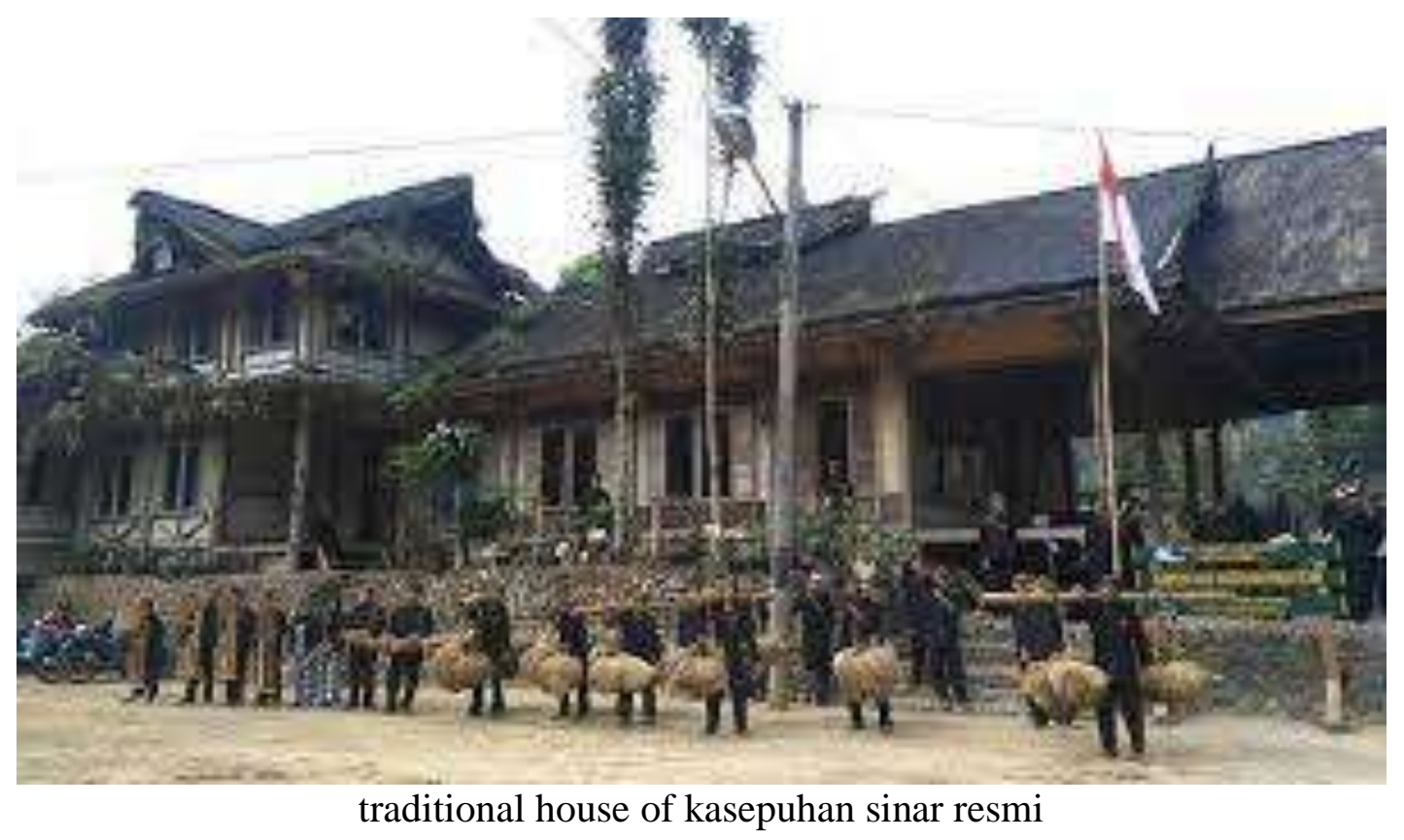

Source: Sukabumi Culture

This Indigenous Community includes three districts, namely:

1. Sukabumi Regency (West Java Province)

2. Bogor Regency (West Java Province)

3. Lebak Regency (Banten Province)

Along with the times and the pace of growth in all fields and responding to this, one of the priority programs within the Banten Kidul Customary Unit is holding the Seren Taun Traditional Ritual Event which is a responsive attitude to the aspirations of the indigenous people around Kasepuhan Sinar Resmi, as evidence of an active role in the framework of efforts to improve the quality of human resources and respect the ancestral heritage, namely by maintaining and preserving the characteristics of their cultural customs.

The basic foundation of adat cannot be separated from the support of regional or central premarital programs that should be developed in the fields of:

1. Strengthens kinship .

2. Religious Education Awareness .

3. Character Education .

4. Maintaining the Customs and Culture

With the maximum efforts of Kasepuhan Sinar Resmi with donors from various circles of society, it is hoped that this Seren Taun Traditional Ritual Program can be held as it should be. 


\section{BACKGROUND OF KASEPUHAN SINAR RESMI}

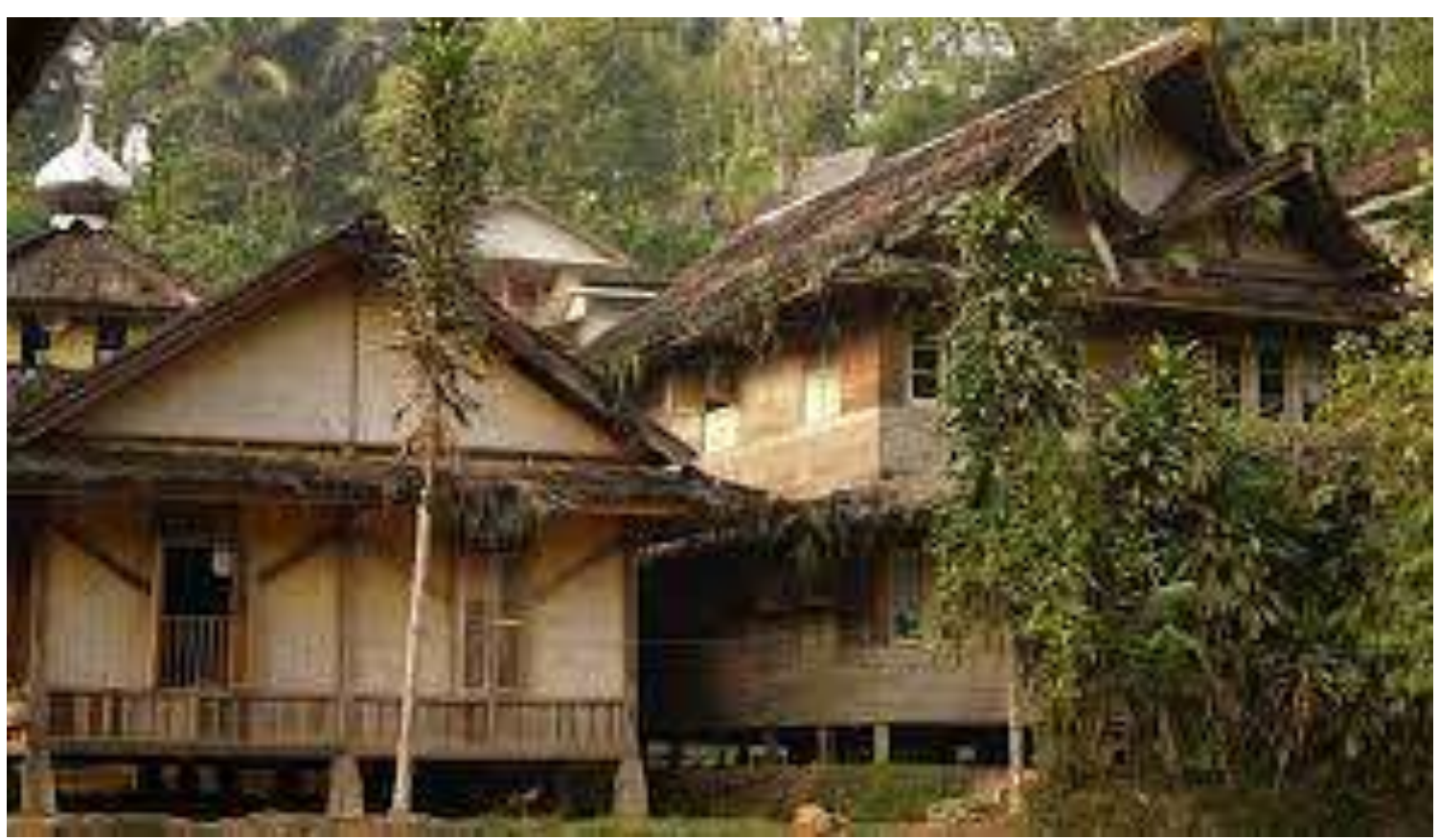

Tradisional House of kasepuhan sinar resmi

Source: Sukabumi Culture

Indonesia is a country consisting of various ethnic groups spread throughout Indonesia. Each tribe has a different culture from Sabang to Merauke. therefore, the country has a high cultural diversity. It is through this cultural diversity that makes a national identity that must be maintained and preserved. From time to time, and the brunt of the globalization era is increasing, this causes many foreign influences to enter which are difficult to contain and the strong influence of globalization can result in the erosion of the culture that is owned by a region in Indonesia. However, with the belief to maintain a culture, the culture is maintained and preserved. This belief is owned by a community that seeks to maintain and preserve and maintain a culture called an indigenous community.

Indigenous communities are communities that live based on ancestral origins on customary territories that have sovereignty over land and natural resources, social life regulated by customary law, and customary institutions that manage the sustainability of community life. One of the indigenous communities in Indonesia and until now still adheres to the accompanying customary rules, namely the Kasepuhan Sinar Resmi customary community, Sirna Resmi 1 Village, Cisolok District, Sukabumi Regency, West Java Province. The indigenous people of Kasepuhan Sinar Resmi are a community with all its local wisdom which in their daily lives, carries out traditional socio-cultural practices that refer to the characteristics of Sundanese culture in the 18th century.

The Resmi Kasepuhan is one of eleven kasepuhan located in the South Banten region. This community has lived from generation to generation from generation to generation, 
this identity is still maintained and strengthened as an embodiment of gratitude and respect for the ancestors who were born from an unbroken historical process in the course of time to continue to uphold the dignity and rights of origin as cultural identity and national cultural heritage. With a system inherited from their ancestors, the indigenous people of Kasepuhan Sinar Resmi organize their entire lives, both as individuals and as distinctive social and religious groups, which differ from one another. These systems are maintained and fought for as a source of the spirit of life contained in the customary system that is still being cultured and preserved.

\section{RATIONALE}

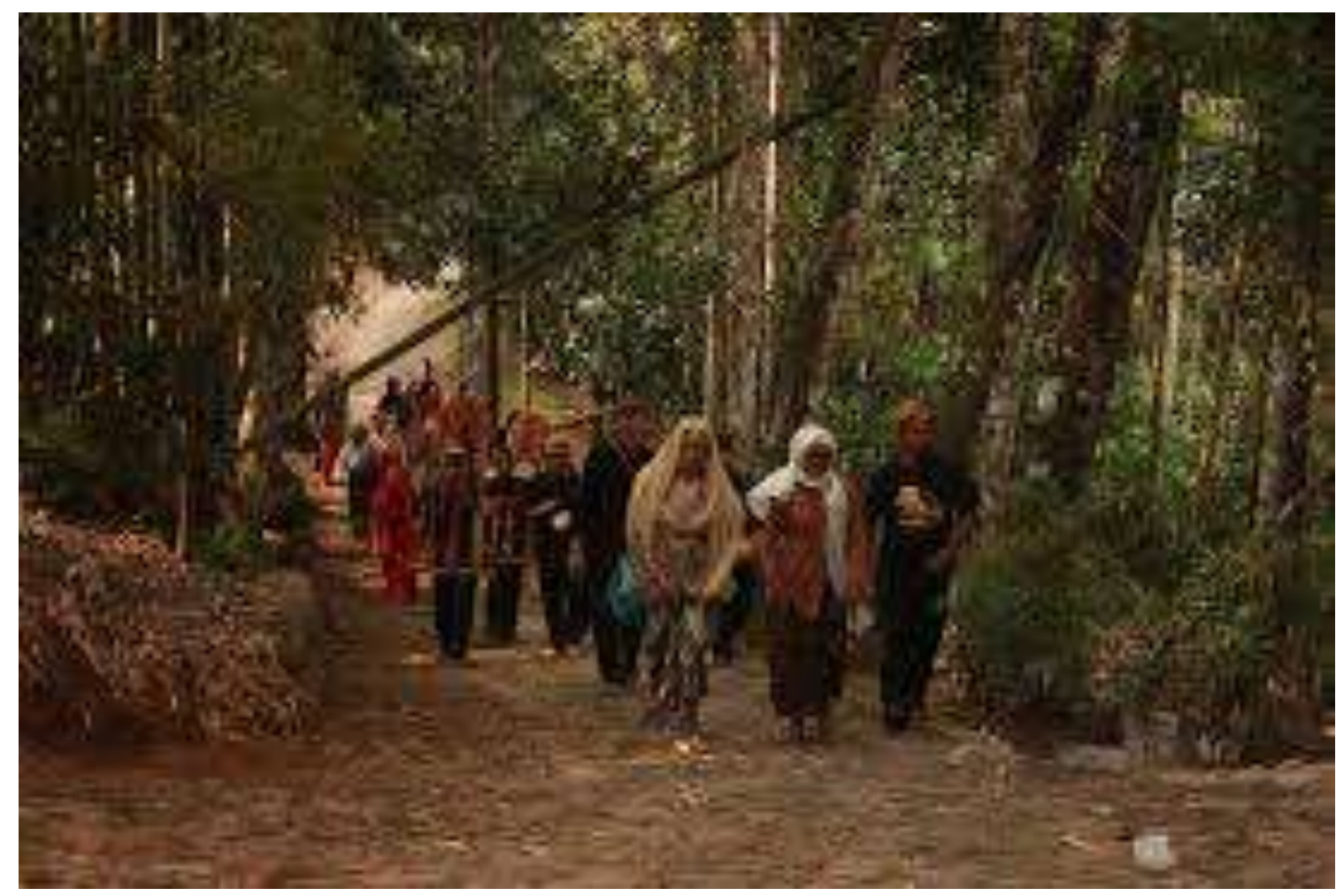

Road infrastructure

Source: Sukabumi Culture

The Kasepuhan Sinar Resmi indigenous people are never separated from the philosophies of life that have become one soul in the Kasepuhan indigenous people themselves. This philosophy is the guideline for people's lives. In social life, the basis of the Kasepuhan customary law is the philosophy of life, "tilu sapamulu, dua sakarupa, hiji eta-eta keneh", which literally means 'three faces, two like, the same one'. understanding that life can only take place well and peacefully if three conditions are met, namely:

1. (determination, speech and lampah, (intentions or thoughts, words and actions) must be in harmony and can be accounted for to incu-putu (descendants of kasepuhan residents) and elders (parents and ancestors)

2. soul, body and behavior, must be in harmony and have character

3. the traditional beliefs of sara, nagara, and mokaha must be in harmony, harmony and not conflict with one another. In addition to guidelines in socializing between communities, the kasepuhan community has an interaction with nature. Through 
the philosophy of "Mother of the earth, father of the sky, land of the queen" whose essence in life, people must maintain the integrity of the earth and all its contents so that the balance of nature is maintained. Based on these philosophies, the Kasepuhan community has the belief to continue to maintain what has been inherited by their ancestors, both maintaining relationships with other humans and maintaining relationships with nature.

One of the ancestral heritage that is still applied in the life of the Kasepuhan community is the agricultural system of fields/huma (rurukan) and rice fields which is carried out once a year. This agricultural system is not just an agricultural activity that generally leads to productivity, but the agricultural system in the Kasepuhan Sinar Resmi indigenous community is more oriented towards a strong interaction between the community and God, the community with the community and the community with nature. In managing the agricultural system, starting from preparing the land to resting the land again, it is always followed by a series of accompanying traditional ceremonies or rituals that have been passed down by the ancestors.

\section{DESTINATION}

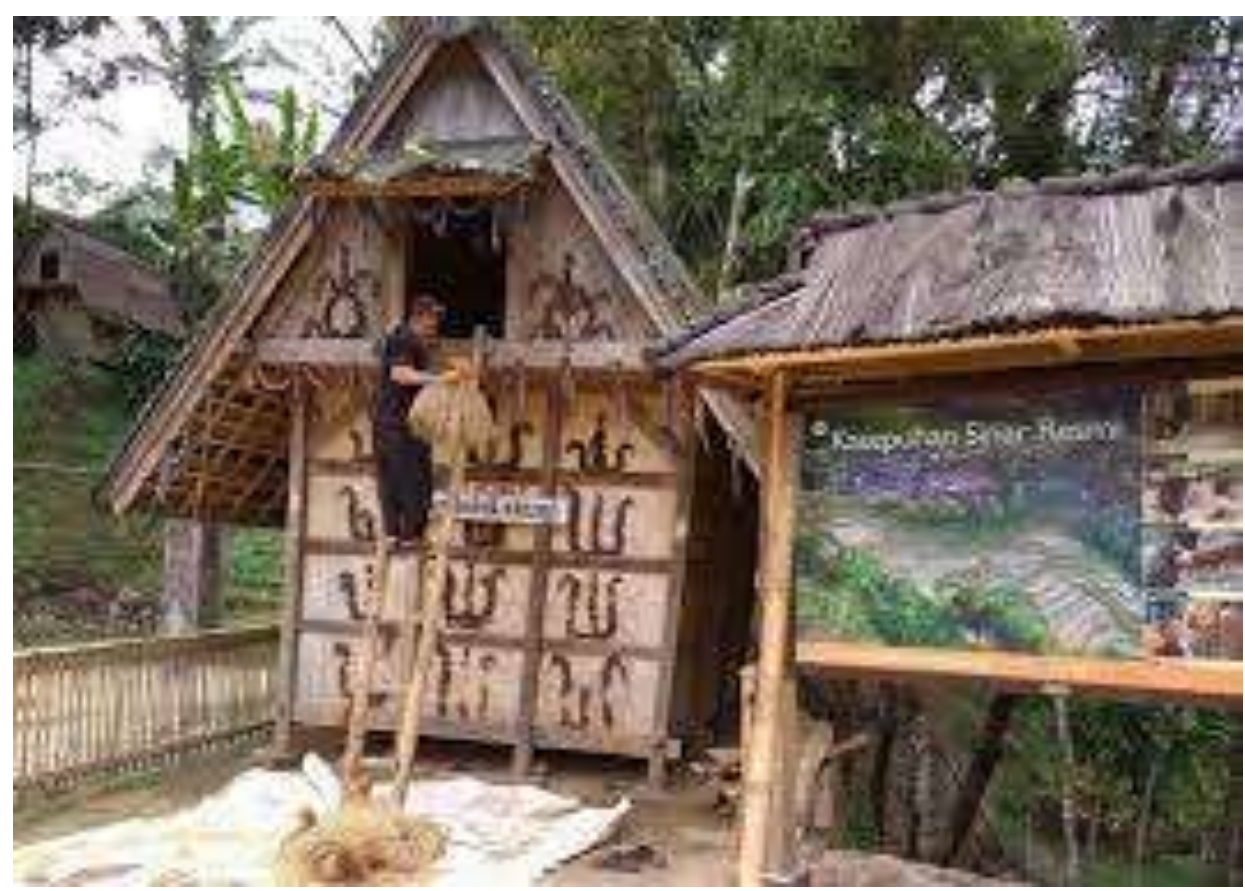

Harvest storage warehouse

Source: Sukabumi Culture

1. Preserve and maintain the traditions inherited from the ancestors.

2. Strengthening the unity and integrity among indigenous peoples, non-indigenous communities, and the government.

3. Preserving one of the cultures of Indonesia's cultural diversity

\section{HOPE}




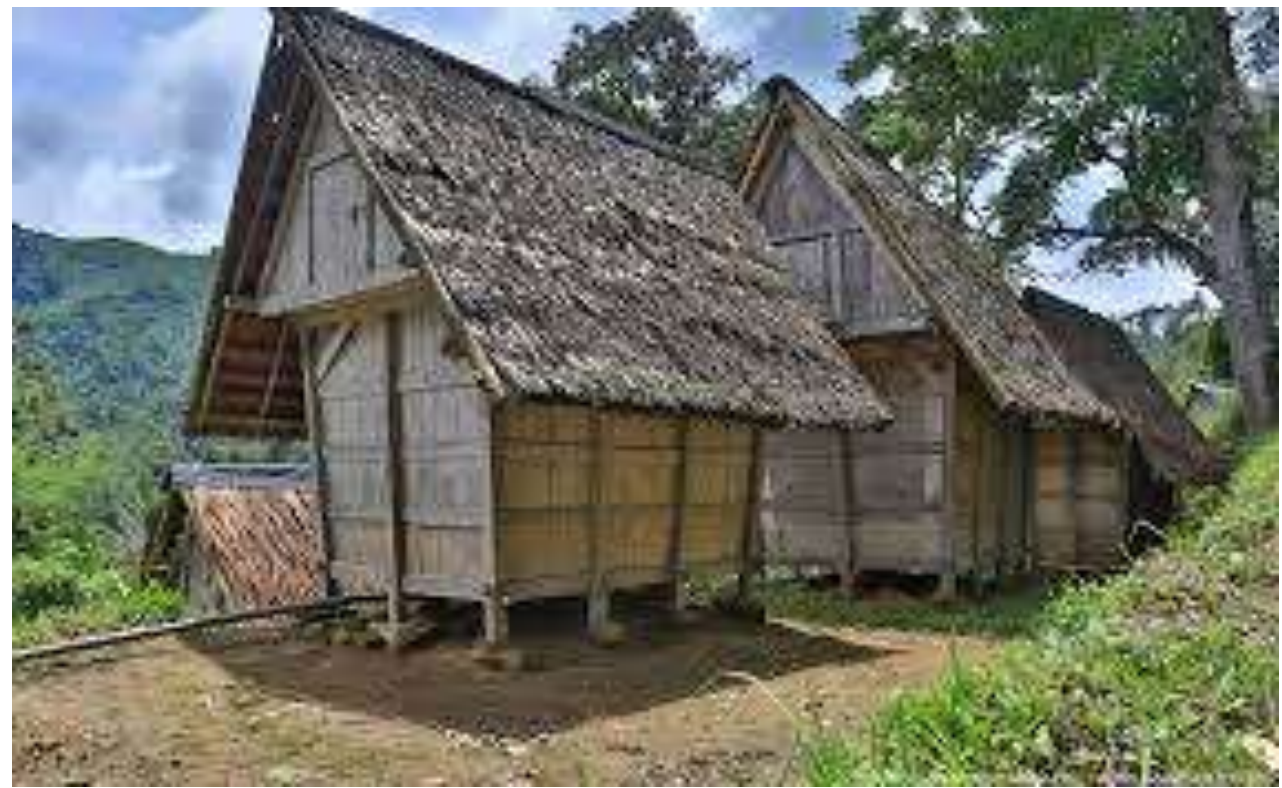

Harvest storage warehouse

Source: Sukabumi Culture

The indigenous people of Kasepuhan Sinar Resmi as a community that cannot be separated from the accompanying traditional traditions in this case indirectly have a fairly influential role in maintaining the integrity of Indonesian culture, namely through traditional agricultural systems and other customary activities. Therefore, full attention is needed from the government as one of the actors who participate in supporting the sustainability and maintenance of customs that have existed since the past until now.

\section{ACTIVITY DESCRIPTION}

Traditional rituals performed in Kasepuhan Sinar Resmi are carried out routinely and repeatedly, on a monthly and annual basis. The monthly ritual performed is opatbelasna, which is performed every month. The annual ritual is related to the agricultural system, the procession of rice and field farming, Alms Ruwah and Mulud, Prah-prahan, Nyimur, Beberes Bengkong, as well as the Seren Taun ceremony which is held once a year.

\section{About Agriculture In Kasepuhan Sinar Resmi}

Kasepuhan Sinar Resmi is located in the village of Sirna Resmi, Cisolok District, Sukabumi Regency (about $27 \mathrm{~km}$ from the city of Palabuhanratu). The main livelihood of the Indigenous Sirna Resmi is traditional farming. What is special and applies to the indigenous people of Kasepuhan Sirna Resmi is, "Rice, is the only agricultural product that cannot be traded (Pamali), or in other words, rice and rice in the Kasepuhan Sinar Resmi environment are not "commodities" that are free to be sold. belikan. What is more interesting is the local and traditional wisdom that has a positive impact on the 


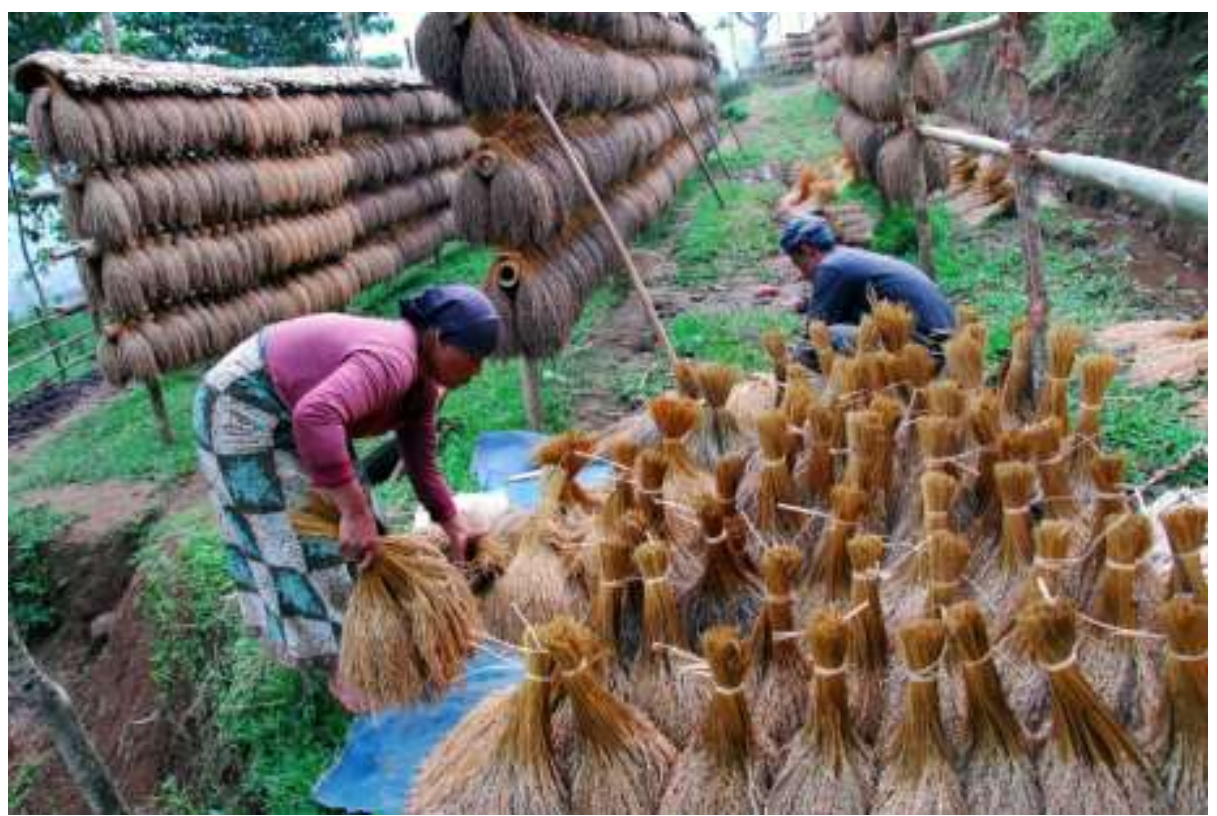

Harvest of kasepuhan sinar resmi

Source: Sukabumi Culture

sustainability of the maintenance of local rice seeds (origin pare). In the case of rice cultivation, the customary holder is in the position of the authority to maintain the seeds. Each incu putu can only plant the seeds that are given and have received the blessing of the Resmi Kasepuhan Sinar Customary Pupuhu, the Resmi Kasepuhan Sinar traditional Pupuhu is Abah Asep Nugraha. Thus, the sustainability of local seed maintenance is maintained. Likewise, until now, Kasepuhan Sinar Resmi still owns and maintains rice seeds of around 68 types of local rice varieties consisting of huma rice and lowland rice that still exist and are planted in the Kasepuhan Sinar Resmi area.

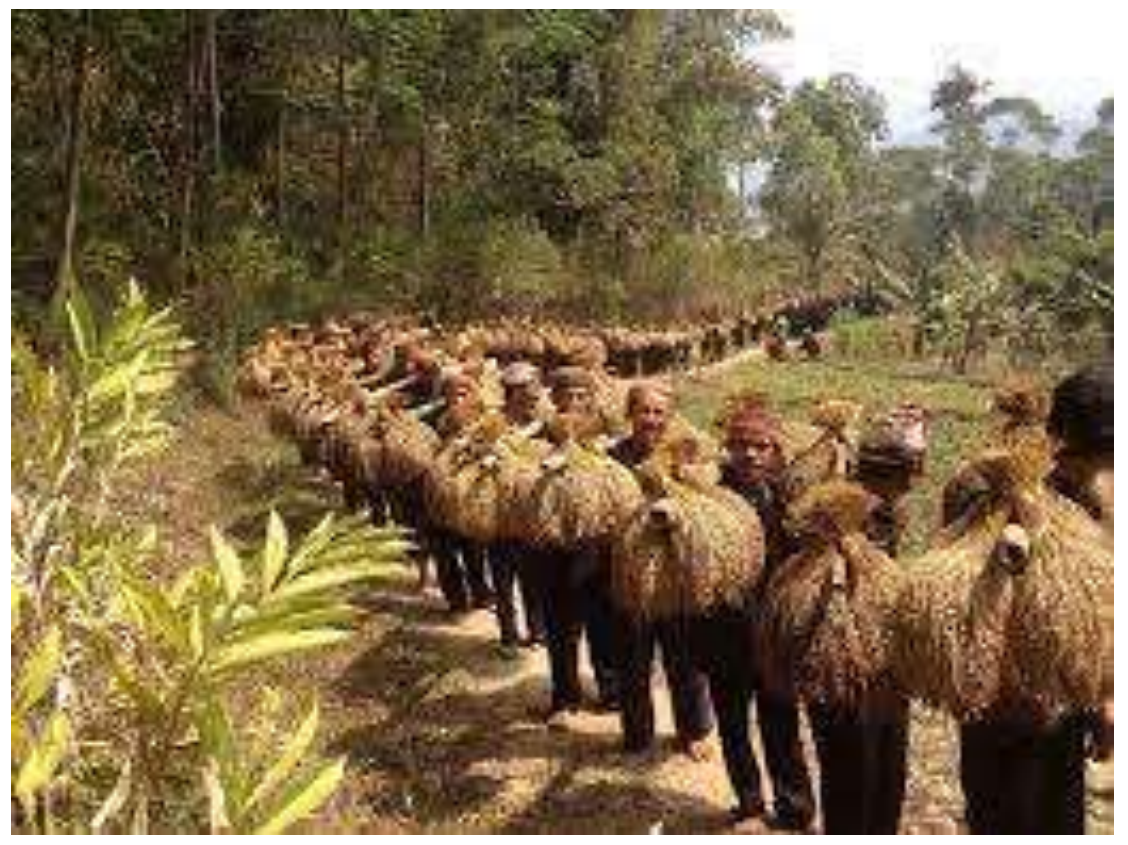

Harvest of kasepuhan sinar resmi

Source: Sukabumi Culture 
In accordance with the Government's determination to be able to produce 2 million tons of national rice, Kasepuhan Sinar Resmi responded to this program and was very realistic considering the potential of agricultural land, both rice fields and field / huma farming.

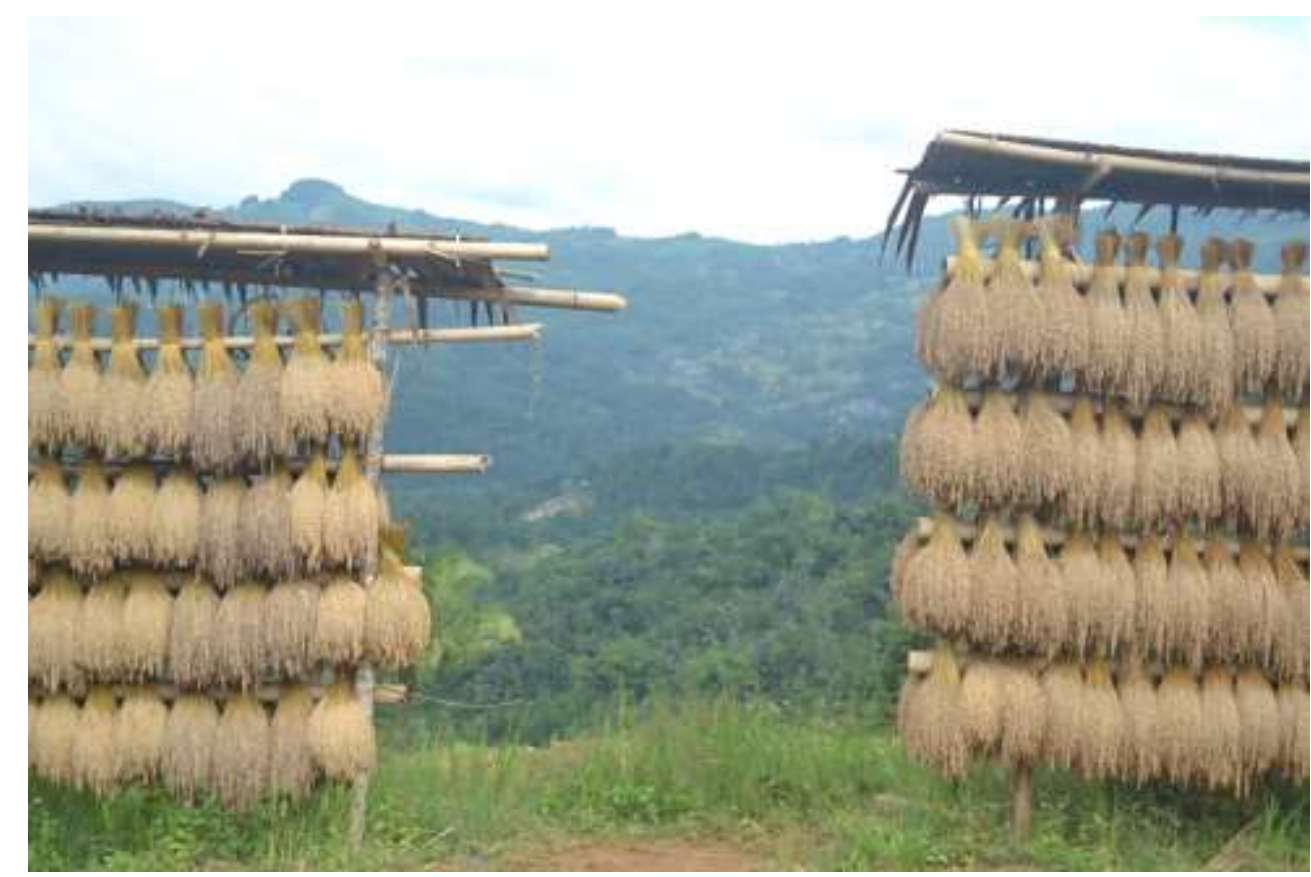

Harvest of kasepuhan sinar resmi

Source: Sukabumi Culture

The role of government and non-government institutions such as the Kasepuhan Sinar Resmi Indigenous community led by the Kasepuhan Sinar Resmi Pupuhu, namely Abah Asep Nugraha, in this case is quite thick. This is because the Resmi kasepuhan traditional light, which is located in the Resmi Sirna village, Sirna Resmi Village, Cisolok District, Sukabumi Regency, West Java Province, which is led by Pupuhu Adat Abah Asep Nugraha, is closely related to supporting food security programs and wants to maintain and preserve the large number of local rice varieties there are 68 types of local rice varieties that still exist and are spread around the Kasepuhan Adat Sinar Resmi environment. Apart from being a facilitator of Kasepuhan Sinar Resmi between the indigenous people of Kasepuhan Sinar Resmi and the Government as well as a unifying relationship between individual indigenous peoples, especially those in the Kasepuhan Sinar Resmi environment, in this case there is a need for new breakthroughs and encouragement from the government so that the Empowerment Preservation Program and improvement The quality and quantity of these 68 local varieties of rice in the Kasepuhan Sinar Resmi environment can be achieved.

\section{Art of Laes Or Lais From Kasepuhan Sinar Resmi}

Laes Art Or Lais From Kasepuhan Sinar Resmi - Lais art is taken from the name of someone who is very skilled in climbing coconut trees named 'Laisan' who is called Pak Lais everyday. The first attraction is the pelais climbing bamboo and then moving to the mine while dancing and spinning in the air without using a seat belt, accompanied by 
beats such as dog-dogs, drums, kempul and trumpets. This art has existed since the Dutch colonial era.

This art is an acrobatic performing arts in a 6 meter long rope that is stretched and linked between two bamboos with a height of 12 to 13 meters.

Lais art is taken from the name of someone who is very skilled at climbing a coconut tree named "Laisan" who is called Pak Lais everyday. This lais has been known since the Dutch colonial era, its place is in Kampung Nangka Pait, Kec. Sukawening. The attractions that are watched are first the pelais climb bamboo and then move to the mine while dancing and spinning in the air without using a seat belt to the accompaniment of reog music, pen drums, dogs and trumpets.

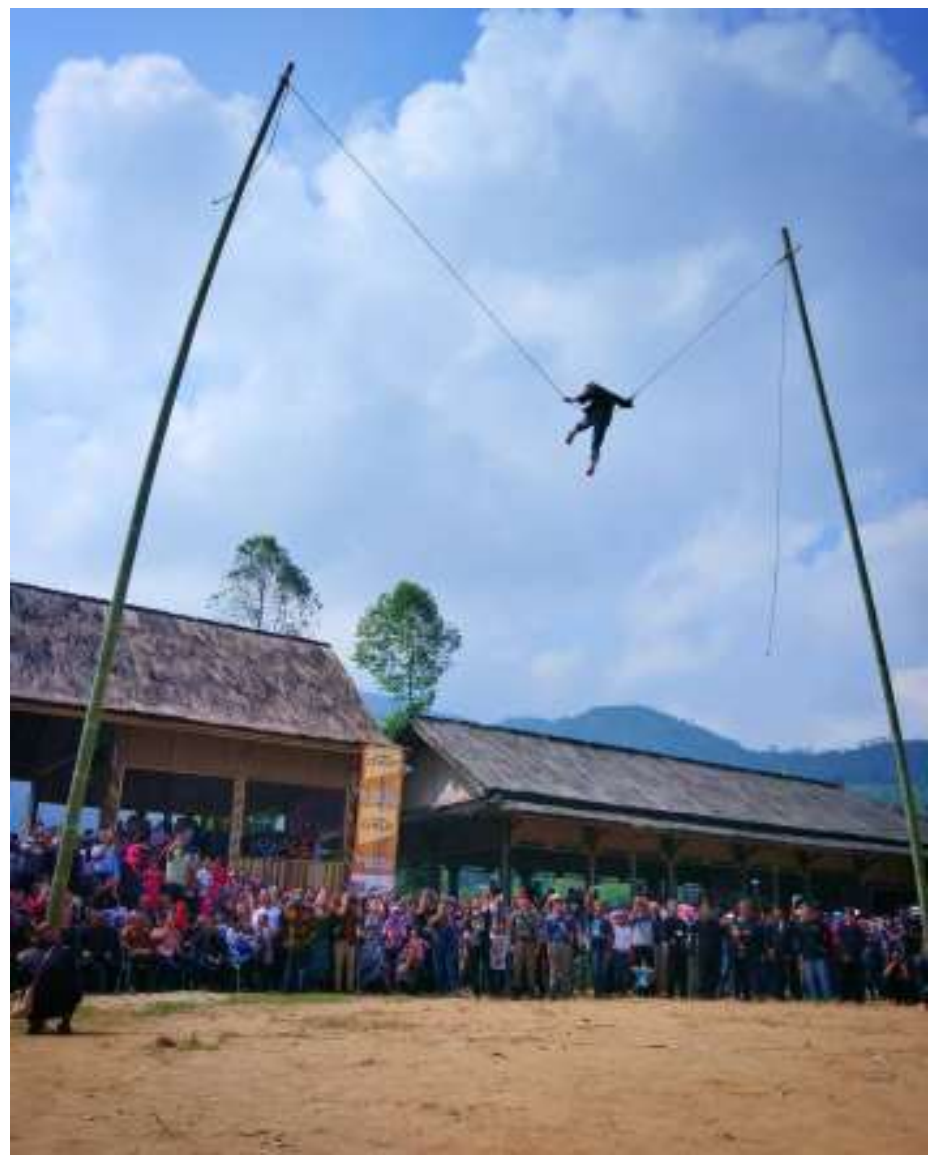

Laes traditional art

Source: Sukabumi Culture

Lais is a type of folk performance in West Java that is similar to acrobatics. However, because any activity in this traditional Sundanese society cannot be separated from the beliefs of its inhabitants, the acrobatic skills performed by the lais players are also believed to receive supernatural assistance. Apart from that, of course, lais is also given a breath of art by the inclusion of drums and singing songs during the performance. 
Lais performances mainly show the skills of one or two lais players who walk or sit on a rope stretched between two ends of the bamboo. The rope is always swaying and the bamboo moves while supporting the weight and movement of the laissmen.

Lais are found in Sukabumi, Sumedang, Garut, Tasikmalaya, Ciamis, Cirebon and Bandung regencies. Lais can be witnessed at state events, celebrations, weddings or circumcisions.

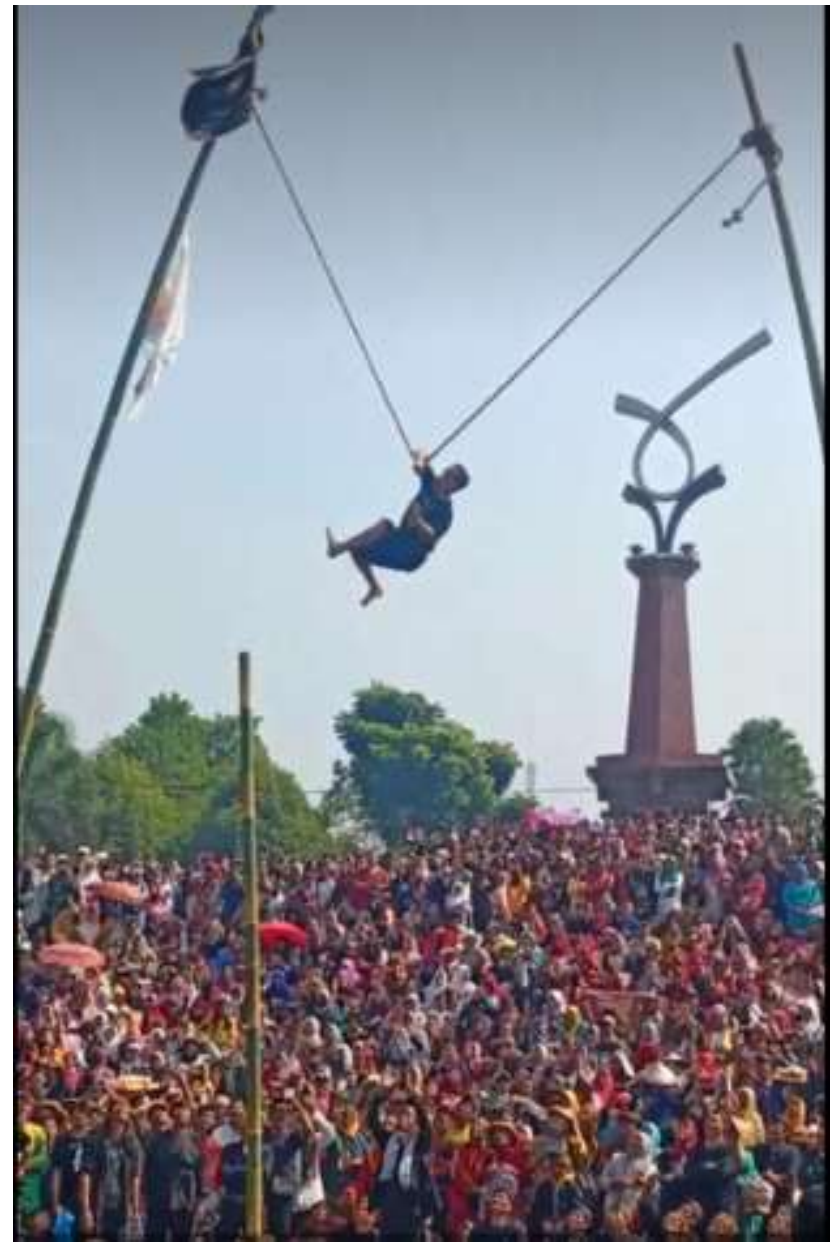

Laes traditional art

Source: Sukabumi Culture

The way of presenting the lais performance is done by first placing two leunjeur (stems) awi gombong (big bamboo) on the ground and stretching the ropes at both ends of the bamboo. The rope is then tied to the two ends of the bamboo sticks, then the beat is sounded as an opening as well as a notification that the game will start soon. This is done to invite the audience and to warm up the atmosphere.

When the game starts, the shaman (handler) lais is ready with the ceremonial equipment, namely offerings (offerings) and censer (steam). Along with the sound of the beat, the incense in the censer was burned and incantations were recited. This ceremony is intended so that the lais player is given strength, agility, skill and safety in the game. 
The clothes worn by lais players are clothes commonly worn by women such as cloth and kebaya, especially lais players in Priangan. With graceful steps, the laiss player, who is believed to have started to get possessed by the supernatural spirit, danced close to one of the bamboo poles. He tucked an umbrella around his waist. At that time a conversation took place between the laissist and the handler. The conversation is as follows:

Handler: "Where are you, Nu Geulis?"(Where are you going, Cantik?)

Si Lais: "What rek ulin." (I want to play.)

Handler: "Nyandak naon?" (Bring what?)

Si Lais: "Ieu umbrella hot bisi jeung duwegan bisi halabhab." (Here's an umbrella in case it's hot and a young coconut in case you're thirsty.)

Handler: "Pek atuh geura amengan." (Please if you want to play.)

While dancing again, Si Lais continued to approach the bamboo pole and skillfully climbed the bamboo pole like a monkey. The way to climb it is by not pressing the body to the bamboo stem, but by using its hands and feet.

When Si Lais climbs the bamboo sticks, the accompanying wasps are sounded louder and louder until Si Lais reaches the top of the bamboo sticks. After arriving at the rope that was stretched, then Si Lais sat at the end of the bamboo relaxed and relaxed, then he sang but only the sound of his mumbling without words. The handler below asked again while tilting his head.

Handler : "Hey, Geulis, keur naon?" (Hey, Beauty, what are you doing?)

Si Lais: "What the hell is it going to be fun!" (This is just having fun.)

Handler: "Cing, Geulis, ngojay bangkong area." (Try it, Beauty, you swim like a frog.)

Si Lais: "Mango," with a smile

Then Si Lais lay face down on the end of the bamboo and pressed his stomach and made movements like he was swimming.

Si Lais: "Oops capejeung hanaang." (Oh, I'm tired and thirsty).

Si Lais then sat down again on the end of the bamboo, then split the young coconut he was carrying with a machete. In addition to Si Lais' skillful movements, his behavior also makes the audience's heart flutter, especially the female audience. When Si Lais splits a young coconut, his knees are used as prisoners and the coconut water is drunk while lalagedayan (relaxing or lying relaxed while swaying his legs). After drinking the young coconut water, Si Lais went down by walking along the bamboo by sliding.

After reaching the bottom, Si Lais danced and the machete he was carrying was placed near the musicians, then he climbed back up to the top of the bamboo pole and stood there. He took the umbrella tucked around his waist. Using the umbrella, he climbed (walked) on the rope that was stretched earlier.

In the middle of the mine he danced, sang and rocked his body. This attraction is the culmination of the popular game. Many of the audience held their breath and some shouted because they were worried that Si Lais would fall, especially the female audience. 
Si Lais pretended to show movement when he slipped, thereby making the audience hysterical. In his pretense he chattered. "Ouch ..... Wow ..... Watch out," and ... "La la la," he sings incessantly. After being satisfied with playing with the audience, he walked towards the other end, then while standing at the end he danced to the beat of the drums from below.

When finished, Si Lais went down by sliding. The beats from below continued to sound and the trumpeter blew his trumpet with cheerful songs. This is done to give other players time to rest.

After finishing resting, Si Lais went back to climbing the bamboo. He showed his game by swinging in the middle of the mine with his legs hanging. While walking on the mine, he took off the woman's clothes he was wearing by ngorondang (crawling).

After finishing his performance, he went down again down the mine and this was the end of the Si Lais laiss show and was then brought into the house by the handler. When he came out, Si Lais acted as usual and his clothes had been changed to normal clothes.

The lais show takes half a day or even a full day, depending on the invitees. The waditra used to accompany lais performances is the same as the waditra used in pencak drums, but added with dogdogs and angklung. The lais players consist of 6 adult men, namely one lais player, one handler who sometimes doubles as the leader of the lais and the others are musicians.

Lais games are usually held in an open arena such as a field or square where the place is considered wide to stick bamboo poles with a distance of 10-15 meters between one bamboo pole and another. Lais performance is not part of a ceremony. Therefore, it can be called at any time. This popular game is passed down by the family to each successive generation.

Reference: http://amochiqa189.wordpress.com/2008/04/16/kesenian-lais

\section{The Art of Dog Dog Lojor Kasepuhan Sinar Resmi}

Definition

Dogdog Lojor is a string of two words, namely dogdog and lojor. Dogdog is a percussion instrument made of a hollow wooden stick with a circle with a diameter of $15 \mathrm{~cm}$ and a tapering tip with a diameter of $12-13 \mathrm{~cm}$, while the length is approximately $90 \mathrm{~cm}$ to 100 $\mathrm{cm}$. At the end of the circle with a diameter of $15 \mathrm{~m}$, it is covered with dried goat skin, then tied with a bamboo rope and put on a wedge to tighten the skin, so that when hit, it will make a dog.. dog.. dog sound. Finally called the musical instrument dogdog. While lojor (Sundanese dialect of Banten) means 'long'. Usually dogdogs that are common in length are between 30-40 cm. Dogdog lojor has a length of $90-100 \mathrm{~cm}$. So, dogdog lojor is a long dogdog.

Function 
The Seren Taun Ceremony, the Alms Ceremony, the Ruwatan Ceremony, the celebration of the 40th birthday of the baby, and the Ngabaladah Ceremony 'opening' a new field and the marriage ceremony, are ceremonies that are always accompanied by the art of dogdog lojor.

The people of Banten, especially the Baduy people, have ceremonies that are considered sacred and magical, such as the ceremony above. Here, dogdog lojor plays a very important role because this art is considered a bogus art and contains magical values.

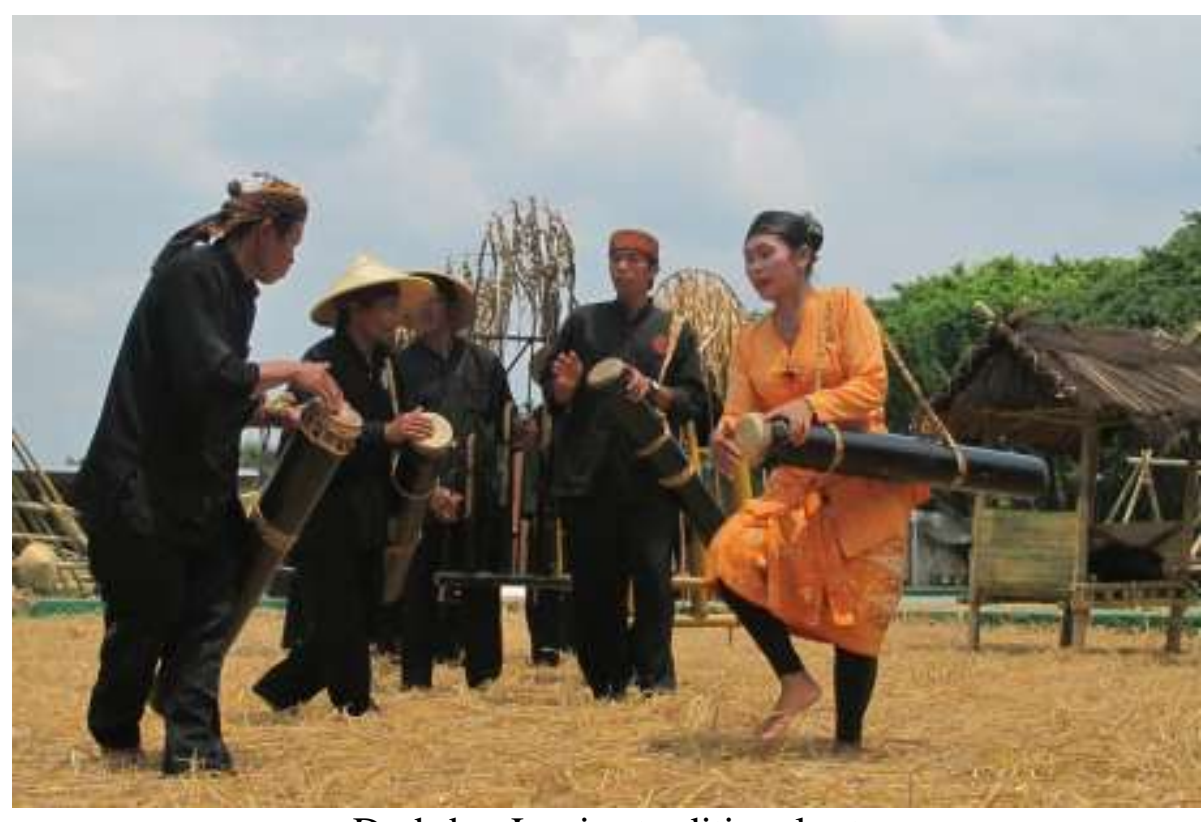

Source: Sukabumi Culture

Dod-dog Lonjor traditional art

The art of dogdog lojor can be used as a means of expressing gratitude, an expression of refusing reinforcements, and an expression of offering, or even an expression of joy. All can be seen in the ceremony that carries it out. However, in today's development the art of dogdog lojor is fading, from an art that is considered sacred and magical to an entertainment art that can be performed anytime and anywhere. 


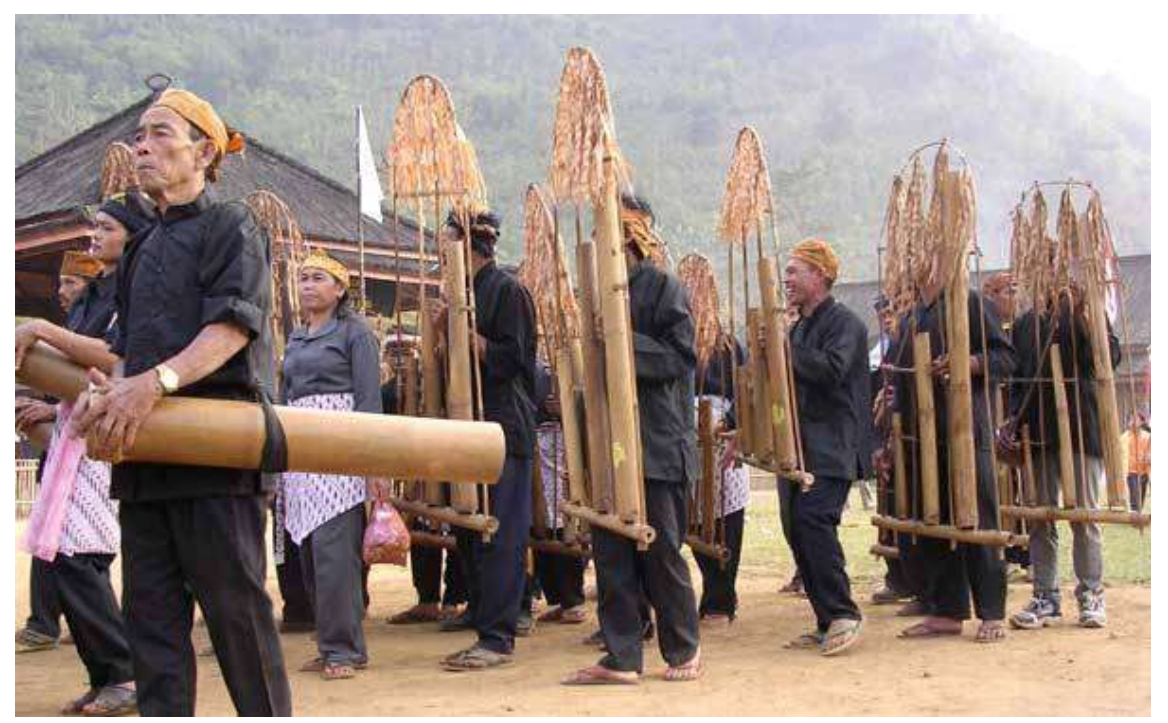

Dod-dog Lonjor traditional art

Source: Sukabumi Culture

Players and Waditra

The players required in this art are at least 12 people consisting of 4 dogdog players and 8 angklung players; who were divided into two groups with the same number of people. The players are not monopolized by men alone, now with the demands of the times, women can also play this art. Waditra used in this game are dogdog and angklung.

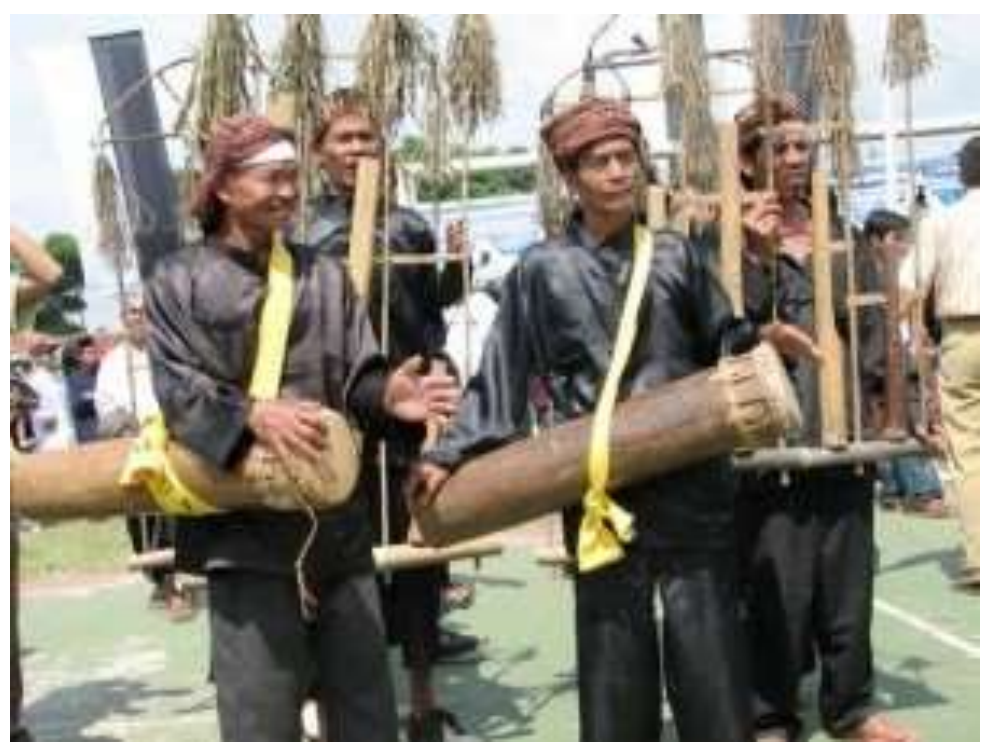

Dod-dog Lonjor traditional art

Source: Sukabumi Culture

Game Path

Beginning with the dogdog stroke as a signal for the angklung player, then the game \pm 1 starts with the pakpak pong dogdog stroke, sir........... Sir....... pong, in unison the angklung players sounded their angklung by singing the song "Bean Beans" or "Tongeret". 
String bean

Cis chickpeas nyengcle

Ti anggolati horse

$\mathrm{Nu}$ geulis tembong pingping

Keun bae jang kaula

Cis chickpeas nyengcle

Cinnamon flowers are squeaky

$\mathrm{Nu}$ geulis keur ngalewe

Jerenges awesome

Tongeret

Tongeret

Tongeret kerrmiiiiiii

Tamiang to the side

Awewe wantererrrrrrrrrrr

Usually the instrument "Tongeret" is the basic rhythm that constantly accompanies this game of dogdog lojor art.

This dogdog lojor game consists of:

Worms

Oray-orayan

Beat the drum / dogdog

Sheep

Ngadu road

The various waditra games above, give rise to various movements of the players so that they look very dynamic with the hoyah screams of the players. :as well as their agile demean play angklung and dogdog in various friends earlier.

Some of the terms of this game are the same as the dogdog lojor game in West Java:

Angklung Beans Priangan area

Angklung Gubrag Bogor area

Bedug Lojor area of South and North Banten

Angklung Bungko Cirebon area

Badeng Badud in the northern Priangan area

The lojor dogdog distribution area is in southern Banten, namely Bayah, Carucuk, Ciherang, Cisungsang, Cisitu, Citokek, Cinangka, and Kanekes Baduy, also in Sukabumi, especially in Sirnaresmi and Ciptarasa Cisolok.

The figures who contributed to the development of the art of dogdog lojor are: 
In Cibeber District, Lebak Regency:

Mr Oco

Mr. Mansour

Mr. Okri

Lebak Regency Jackfruit Sand:

Wulung Banner

UPEC led by Mr. Uhen Cikotok.

Source: Masduki Aam et al. 2005 Banten Province Traditional Arts Department of Culture and Tourism Bandung Historical and Traditional Values Study Center

\section{The Ritual of Kasepuhan Sinar Resmi Seren Year}

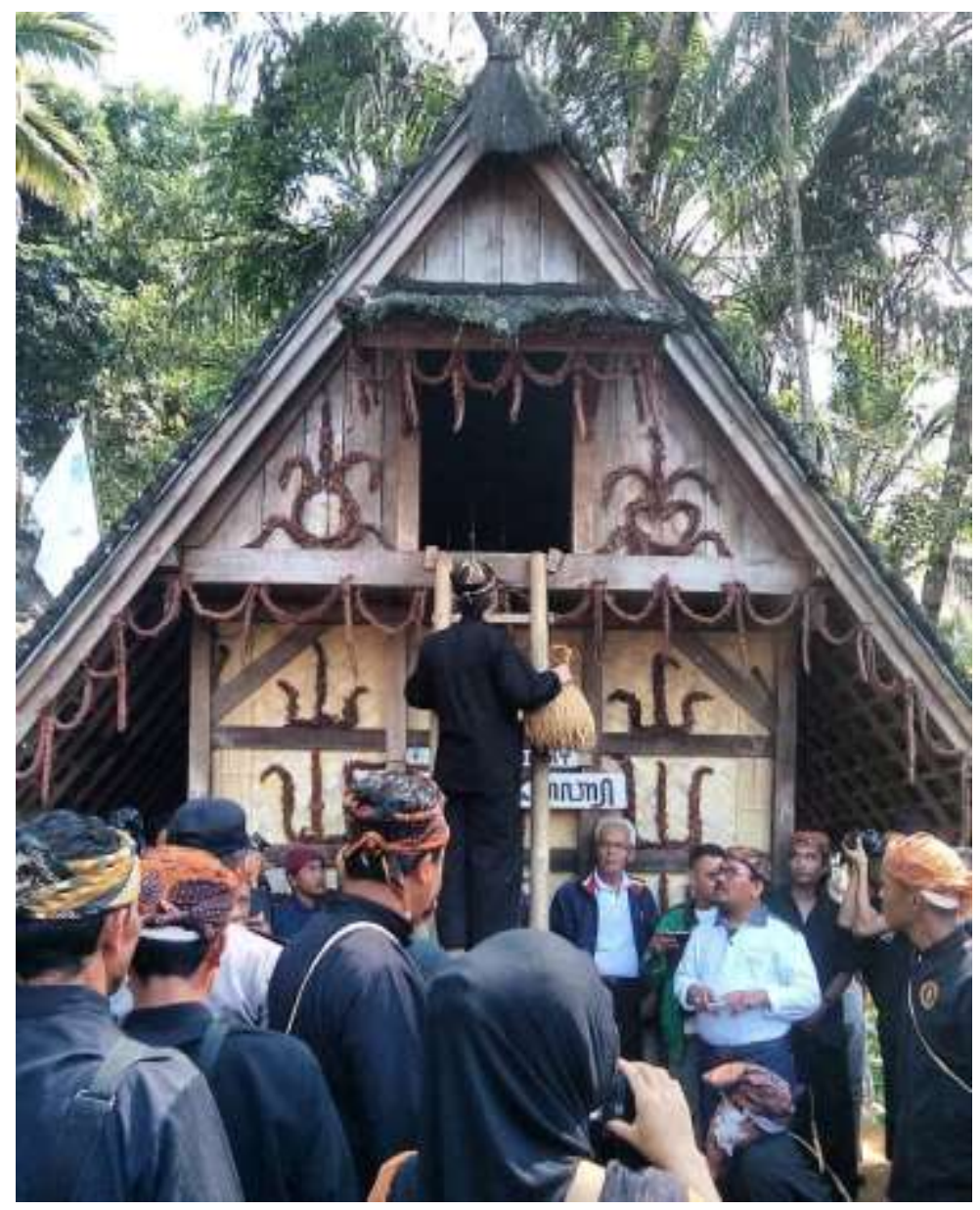

Ritual of Seren Taun 
Source : Sukabumi Update

Seren Taun is a ritual ceremony / expressing gratitude for the current year's harvest, that is how the gratitude of the Kasepuhan Sirna Resmi indigenous community is led by the Indigenous Stakeholder, namely Abah Asep Nugraha. Seren Taun is an activity where a very sacred ritual is carried out once a year where the indigenous people of Kasepuhan

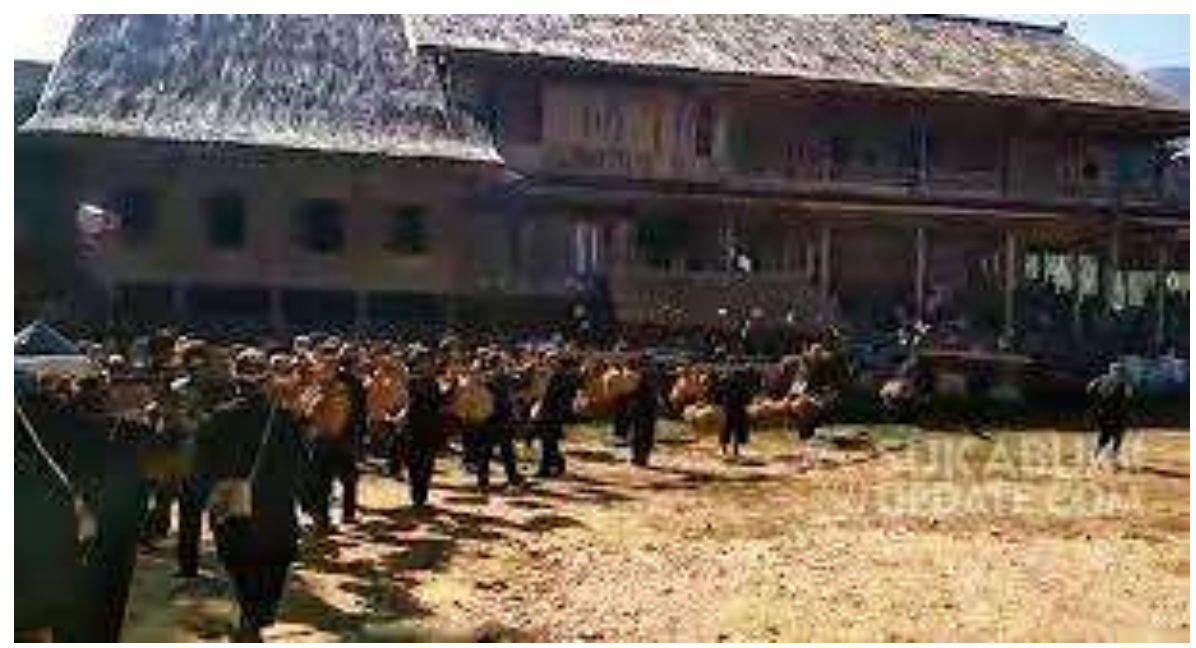

Ritual of Seren Taun

Source : Sukabumi Update

express their gratitude for the abundant harvest and success in farming even though they cultivate once a year and can meet their rice needs within a year. every rice harvest, whether rice from the fields or rice from the fields (huma) the indigenous people of Kasepuhan Sirna Resmi store their harvests in the leuit (rice storage area) and seren taun is carried out after every rice harvest (pare harvest).

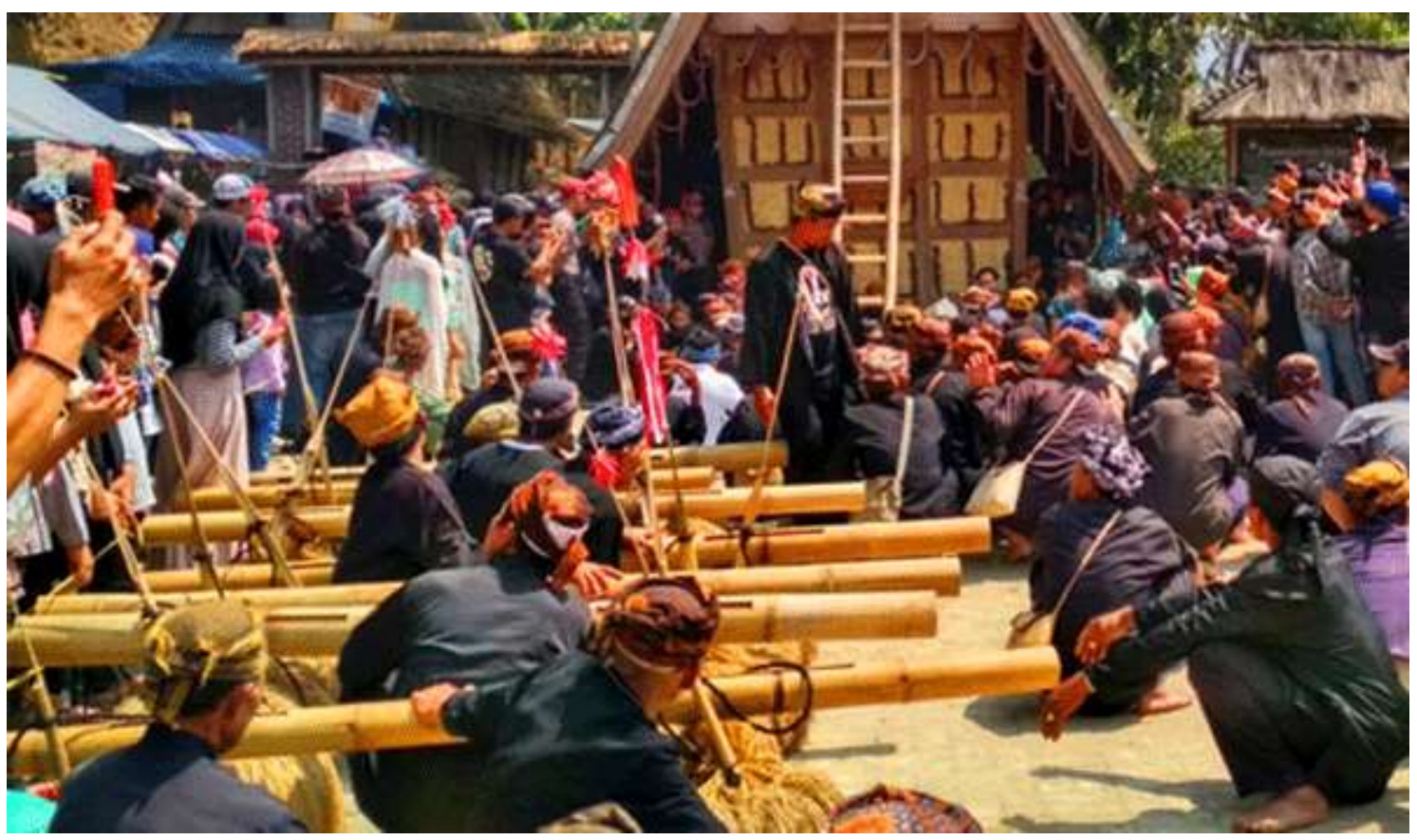


Source : Sukabumi Update

\section{Ritual of Seren Taun}

every Seren Taun activity is followed by various levels of society, both the Kasepuhan indigenous people, outside communities and government institutions. In addition to the Seren Taun ritual event by inserting rice into the leuit (ampih pare ka leuit) during the Seren Taun activity there are various kinds of regional arts entertainment that are served to entertain the Sinar Resmi indigenous people and invited guests who come to attend the Seren Taun ritual. every Seren Taun event takes place followed by various communities, both indigenous peoples and from outside the indigenous peoples, the number of people attending reaches thousands.

\section{BIBLIOGRAPHY}

Abdurachman, Maman. (1988). Geografi Perilaku suatu Pengantar Studi tentang Persepsi Lingkungan . Depdikbud : Jakarta.

Endang Naryono. (2020). Sistematika penulisan sekripsi program sarjana. Sukabumi : STIE PASIM Sukabumi

Endang Naryono. (2021).

https://journal.stiepasim.ac.id/index.php/ekonomedia/article/view/52

Hamilton, W. (1979). Tectonics of the Indonesian region. USGS Professional Paper, 1078. https://doi.org/10.3133/pp1078

Katili, J.A. and Koesoemadinata, P., (1962). Structural pattern of South Banten and its relation to the ore bearing veins. Kilatmadju.

Kevie, W.V. (1976). Manual For Land Suitability Classification Por Agriculture Part I Framework For A New Classification System Based On The Fao Framework For Land Evaluation.

Pusat Penelitian dan Pengembangan Tanah dan Agroklimat. (2004). Laporan Akhir Pengkajian Potensi Bencana Kekeringan, Banjir dan Longsor di Kawasan Satuan Wilayah Sungai Citarum-Ciliwung, Jawa Barat Bagian Barat Berbasis Sistem Informasi Geografi. Badan Penelitian dan Pengembangan Pertanian: Bogor.

Pusat Vulkanologi dan Mitigasi Geologi. (2019). Laporan Singkat Pemeriksaan Gerakan Tanah di Kecamatan Cisolok, Kab. Sukabumi, Provinsi Jawa Barat. Badan Geologi: Bandung.

Setiawan, A. Y., Pasya, G. K., \& Rohmat, D. (2018). Nilai-Nilai Tata Lingkungan Terhadap Kelestarian Lingkungan Di Kampung Cikondang Kabupaten Bandung Dan Implikasinya Dalam Pembelajaran Geografi. Jurnal Geografi Gea. UPI : Bandung.

https://doi.org/10.17509/gea.v12i2.1784 
Sugiyono. (2010). Metode Penelitian Kuantitatif, Kualitatif, dan R\&D. CV Alfabeta : Bandung.

Sujatmiko, S. Santosa. (1992). Peta Geologi Lembar Leuwidamar, Jawa (1109-3) Skala 1 : 100.000. Pusat Penelitian dan Pengembangan Geologi , Dirjen Geologi dan Sumberdaya Mineral: Bandung.

Van Bemmelen, R. W. (1949). The Geology of Indonesia. General Geology of Indonesia and Adjacent Archipelagoes. In Government Printing Office, The Hague. https://doi.org/10.1109/VR.2018.8447558 